\title{
How entrepreneur personality affects agrirural entrepreneurial alertness
}

\author{
Chaoyun Liang ${ }^{1}$ iD
}

\begin{abstract}
Academic research on agrirural entrepreneurship and opportunity recognition is scant. Because of this research gap, a series of three studies were conducted to develop a measure of entrepreneurial alertness (EA) in agrirural environments that is empirically valid and easy to administer and to analyze how the personality traits of agrirural entrepreneurs affect their EA. The results indicated that both extroversion and openness affected all of the dimensions of EA, whereas conscientiousness only affected scanning and searching and agreeableness only affected evaluation and judgment. The results also demonstrated interactive relationships between extroversion and openness for all of the dimensions of EA. Our results provide a new understanding of how agrirural EA can be assessed more practically and how personality traits can predict various dimensions of agrirural EA.

Keywords: agrirural entrepreneurs, entrepreneurial alertness, personality traits, scale development.
\end{abstract}

\section{INTRODUCTION}

Responding to various agricultural development problems (e.g., climate change, natural resource limitations, crop instability, and insufficient distribution channels), governments worldwide, including the government of Taiwan, have formulated relevant policies to aid in restructuring and upscaling the agricultural industry (Bachnik \& Szumniak-Samolej, 2018; Chen, Yueh, \& Liang, 2016). Based on this trend, Estahbanaty (2013) suggested that guidance must be provided for agrirural entrepreneurship. Agrirural entrepreneurship has become critical for ensuring increased job security, profitability, food productivity, environmental sustainability, and ecological diversity (Liang, Peng, Yao, \& Liang, 2015; Niemelä, 2015). However, entrepreneurship is

1 Chaoyun Liang, Ph.D., Professor, Department of Bio-Industry Communication and Development, National Taiwan University, No. 1, Sec. 4, Roosevelt Road, Taipei, 10617, Taiwan, e-mail: cliang@ntu.edu.tw (ORCID ID 0000-0001-6608-7717). 
not a quality that agrirural workers widely possess (Khan, Khan, Ahmed, \& Ali, 2012). Among the various skills required of a successful entrepreneur, accurately identifying and selecting potential opportunities have been identified to be essential; explaining the discovery and development of market opportunities is a critical part of entrepreneurship research (Luna-Reyes, Durán-Encalada, \& Bandala, 2013; Omri \& Boujelbene, 2015). Particularly at the initial stage of entrepreneurship (which exhibits the highest failure rate), Shane (2005) verified that entrepreneurs are challenged with chaotic market conditions and may encounter impediments at any time, leading to failure. This concept of entrepreneurial alertness (EA) was first introduced by Kirzner (1997) who defined alertness as the 'ability to identify opportunities which are overlooked by others'.

Improving agrirural entrepreneurship has become a worldwide agenda because of discussions involving government support and promotion, sociocultural trends, and the injection of economic capital (Chia \& Liang, 2016; Niemelä, 2015). Recent meta-analytic studies have reported a significant relationship between personality traits and entrepreneurship, indicating that entrepreneurs are more extroverted, open, and conscientious while being less neurotic and agreeable (e.g., Brandstätter, 2011; Zhao \& Seibert, 2006). However, academic research focusing on the influence of entrepreneur personality traits on EA is limited (Shane, Nicolaou, Cherkas, \& Spector, 2010), particularly regarding their effect on agrirural EA. Because EA is the core of entrepreneurial development, it is crucial to examine how the personality traits of agrirural entrepreneurs affect their EA.

Because of this research gap, a series of three studies were conducted to develop a measure of EA in agrirural environments that is empirically valid and easy to administer and to analyze how the personality traits of agrirural entrepreneurs affect their EA. The first study was conducted to develop a self-report scale for assessing the EA of agrirural entrepreneurs based on Tang, Kacmar, and Busenitz (2012). The second study was conducted to confirm the factor structure of this scale and test the degree of measurement invariance in the scale across genders. The third study was conducted to test how entrepreneurs' personality traits interact to affect their EA.

\section{LITERATURE REVIEW}

\section{Agrirural entrepreneurship}

Changes produced by global warming in physical and biological systems worldwide have become the focus of human society during the past two 
decades. Scholars have advocated that human society must consider the ecological, ethical, and social dimensions of future agricultural practices and the use of rural landscapes (Wilson \& Morren, 1990), with agrirural entrepreneurship being a central concern. Responding to the shifting agrirural economy, numerous U.S. rural communities have become more entrepreneurship-oriented, thus exhibiting a healthy acceptance of controversy in allowing risk-taking and a community willingness to tax itself to maintain infrastructures (Flora \& Flora, 1990). Recently, the Taiwan government introduced various policies for diversifying agriculture (Chen et al., 2016). These nonconventional operations require an appropriately developed entrepreneurial capacity for recognizing market opportunities and optimizing rural resources.

Rural development is increasingly linked to entrepreneurship. Saxena (2012) indicated that entrepreneurial combinations of rural resources include tourism, sport and recreation facilities, professional and technical training, retailing and wholesaling, industrial applications (engineering, crafts), servicing (consultancy), value-added products (from sources such as meat, milk, and wood), and the possibility of off-farm work. New uses of land enable reducing the intensity of agricultural production (e.g., organic production) (Chia \& Liang, 2016; Luna-Reyes et al., 2013). In other words, agrirural entrepreneurs can benefit from opportunities to use local knowledge and experience in exploring rural innovations, evaluating the latest economic developments, and creating new value in rural areas (Sareban, 2012). These entrepreneurs can also benefit from creative problem-solving approaches such as employing high technologies or engaging in global distribution and multinational operations for converting rural risks and environmental constraints into market opportunities (Estahbanaty, 2013).

\section{Entrepreneurial alertness}

In recent years, institutions and individuals promoting rural development have come to consider entrepreneurship a strategic development intervention that can accelerate the rural development process (Niemelä, 2015; Saxena, 2012). Vigorous entrepreneurial activities offer rural economies many benefits; however, they are also extremely risky, ambiguous, and prone to failure. How entrepreneurs identify opportunities in fast-changing environments and how they engage in entrepreneurial efforts have inevitably become crucial challenges (Luna-Reyes et al., 2013; Omri \& Boujelbene, 2015). EA concepts can be used to explain why successful entrepreneurs exhibit an increased sensitivity to and recognize market opportunities that have not yet been exploited by others (Gaglio \& Katz, 2001). Such recognition is an ability 
that agrirural entrepreneurs should develop, which can aid them in forming and actuating future prospects to be used in exploiting the recognized opportunities. Building on McMullen and Shepherd (2006), Tang et al. (2012) determined EA to comprise three dimensions: 'scanning and searching,' 'association and connection,' and 'evaluation and judgment.' This suggestion was applied in the current study.

When entrepreneurs encounter a tangible problem that cannot be resolved using existing organizational systems, they engage in a scanning and searching process, attempting to identify possible solutions. Shepherd and DeTienne (2005) indicated that 'scanning and searching' enables entrepreneurs to think logically and unconventionally, aiding them in establishing personal information databases and expanding their base of personal knowledge. The knowledge acquired through scanning and searching can be translated into an entrepreneur's ability to adapt to new situations. This ability undergirds people's absorption and digestion of external information, thus becoming accumulated experiences. McMullen and Shepherd (2006) suggested that these experiences represent the knowledge stored by an entrepreneur, which can be encapsulated within a specific field and used to benefit from lucrative business opportunities.

Entrepreneurs typically realize the potential of their observations by eliminating interference and concentrating on information details (Lumpkin \& Lichtenstein, 2005). If the information is incomplete or biased because of incorrect information or a partial omission, associating enables entrepreneurs to adjust their current thinking and adapt to the mismatched information sources before formulating options and making unique connections (Gaglio \& Katz, 2001). Entrepreneurs may spontaneously associate irrelevant information with each other by decomposing properties and forming new connections discovered through scanning and searching. Lumpkin and Lichtenstein (2005) explained that entrepreneurs rescanned and researched relevant information within the environment to verify the feasibility of these newly emerging connections.

After the aforementioned processes, entrepreneurs evaluate and judge the gained information pairs to ensure that the formulated ideas match their cognitive framework (Baron, 2006). The extent of evaluation and judgment allows entrepreneurs to discard uncritical messages and enhance their situational awareness. Entrepreneurs may also be required to evaluate, adjust, or reconsider relevant substitutes because additional information can aid them in formulating accurate evaluations and judgments that may lead to new business insights. Dutta and Crossan (2005) suggested that information reappearing most frequently may be more useful in evaluating and judging a framework that adequately explains and matches the new concept, thus 
uncovering a business opportunity. In other words, 'evaluation and judgment' assists entrepreneurs in assessing their willingness to bear the risk and uncertainty of exploiting a particular opportunity (McMullen \& Shepherd, 2006). In summary, for there to be an entrepreneurial opportunity, action must evolve from cues, gathered information, and evaluations (Tang et al., 2012).

\section{Personality traits and entrepreneurial alertness}

The five-factor model (FFM) is a widely accepted personality model (Ariani, 2013; Liu, Ip, \& Liang, 2018), originated by Goldberg (1992). Thompson (2008) then developed the International English Big-Five Mini-Markers (IEBFMM) and confirmed the invariance of the FFM structure across different cultures. The FFM structure comprises the five dimensions of extroversion, openness, neuroticism, conscientiousness, and agreeableness.

Extroversion is associated with sociable, talkative, and self-assured behavior (McCrae \& Costa, 1991). People exhibiting high degrees of extroversion typically enjoy interacting with people and sharing their ideas with others, thereby enabling a cross-fertilization of ideas. However, they can suppress impulses that are socially inappropriate (Wolff \& Kim, 2012). By contrast, people who exhibit introversion are typically reserved, consistent, and prefer to process information internally (Van Der Molen, Schmidt, \& Kruisman, 2007).

Openness is associated with preferring variety, exhibiting intellectual curiosity, and being attentive to broad-minded, reflective, flexible, and unconventional trends (Ariani, 2013; Janowski, 2018). People having high openness scores have an ability to absorb and combine new information, typically seeking a variety of experiences and exploring novel ideas (Baer, Oldham, Jacobsohn, \& Hollingshad, 2008). By contrast, a person with a low degree of openness may behave in a conventional and unanalytical manner (Ariani, 2013).

Neuroticism is a tendency to experience negative emotional states, such as anxiety, depression, fear, sadness, and anger. People exhibiting high levels of neuroticism are prone to thinking irrationally, behaving impulsively, and applying poor coping strategies in stressful situations (McCrae \& Costa, 1991). By contrast, people with low neuroticism scores are typically self-confident, calm, relaxed, and able to face stressful situations without becoming upset (Zhao \& Seibert, 2006).

Conscientiousness refers to a person's degree of organization, self-control, hard work, active planning, and motivation in accomplishing goals (Barrick, Mount, \& Judge, 2001). Highly conscientious people are responsible, reliable, ambitious, purposeful, and achievement-oriented. However, they may focus excessively on task accomplishment, causing them to adhere rigidly to 
established thoughts and behaviors (LePine, 2003). People with low conscientiousness scores are less exacting in applying moral principles (Ariani, 2013).

Agreeableness is associated with being considerate, friendly, compassionate, warm, and willing to cooperate in conflict situations, in addition to preferring positive interpersonal relationships (Janowski, 2018). Although people with high agreeableness scores are unlikely to be preoccupied with avoiding confrontations and conflicts, they can be excessively self-effacing (Bernardin, Cooke, \& Villanova, 2000) and might not claim credit for their contributions (llies, Johnson, Judge, \& Keeney, 2011). By contrast, a person exhibiting low levels of agreeableness can be described as self-centered, ruthless, egocentric, and skeptical of other people's intentions (McCrae \& Costa, 1991).

Several meta-analytic studies have determined strong associations between personality traitsandentrepreneurship, indicating thatentrepreneurs typically have high extroversion, openness, and conscientiousness scores and comparatively low neuroticism and agreeableness scores (e.g., Brandstätter, 2011; Zhao \& Seibert, 2006). Shane et al. (2010) suggested that the trait of openness and the ability to recognize opportunities have the same genetic source. Furthermore, Lim, Lee, and Ramasamy (2015) determined that extroversion, openness, and conscientiousness are strongly associated with EA. In addition, previous studies have shown that the five FFM traits interact with each other, affecting perceived ability or behavior (Pease \& Lewis, 2010; Swickert, Hittner, \& Foster, 2010). Based on the aforementioned studies, the following three hypotheses were proposed:

H1: Extroversion, openness, and conscientiousness positively affect agrirural EA.

$\mathrm{H} 2$ : Neuroticism and agreeableness negatively affect agrirural EA.

H3: Extroversion, openness, neuroticism, conscientiousness, and agreeableness interact with each other to affect agrirural EA.

\section{Study 1: Exploratory factor analysis}

\section{Method}

The participants in this study were agrirural entrepreneurs in Taiwan, serving as the calibration sample for testing the number of factors by using an exploratory factor analysis (EFA). The most appropriate structure of the EA scale was determined by this analysis results. Of the 341 participants, the majority (53.08\%) was male; $22.87 \%$ did not have bachelor's degrees, $35.48 \%$ 
had bachelor's degrees, and $41.65 \%$ had master's (and above) degrees; $16.13 \%$ ranged in age from 20 to 30 years, $25.81 \%$ ranged from 31 to 40 years, $34.31 \%$ ranged from 41 to 50 years, and $23.75 \%$ ranged from 51 and above.

Based on Tang et al. (2012), a 21-item EA assessment was developed by the researchers, which was scored by the research participants to determine the level of agreement with each EA item using a 6-point Likert-type scale ranging from 1 (strongly disagree) to 6 (strongly agree). Regarding the face validity of the assessment, three experts in the agrirural entrepreneurship field were invited to provide feedback. This scale was then completed by approximately 35 agrirural entrepreneurs to test its readability and flow.

The paper-and-pencil survey was administered at three conferences on agrirural entrepreneurship held in Taiwan during December 2014. Identical procedures were followed during each assessment and conducted by the researchers directly; hence, any problems faced by the participants when answering the questions could be resolved. Participation was voluntary, confidential, and anonymous to reduce the possibility of social desirability bias. The questions in this study did not include sensitive items that may have caused the participants to represent themselves dishonestly because of a desire for social acceptability. The participants had the right to review the results of their responses.

\section{Results}

Data were analyzed using SPSS Version 17.0. The measured items were organized by item analysis on the mean range of EA (3.66 to 5.12), standard deviation (0.770 to 1.191$)$, skewness (-0.810 to -0.013$)$, and kurtosis (-1.054 to 0.531 ) of the data acquired during the formal survey. To calculate the item discrimination, the means of the participants involved in the $27 \%$ bottom-top groups were compared through an independent samples $t$-test, indicating the significance level achieved. An item-total correlation test was then performed to check if any item in the scale was inconsistent with the averaged behavior, also indicating the significance level achieved. Cronbach's alpha reliability coefficient was then analyzed $(\alpha>.6)$ to determine the reliability of the scale. The results of the aforementioned analyses showed that the measured items were appropriate.

In this study, the Kaiser-Meyer-Olkin measure was 0.947. Bartlett's test of sphericity was significant $\left(\chi^{2}=5826.038, d f=210, p=.000\right)$. Both analyses showed that the sampling was sufficient to proceed to the factor analysis. A Principal Axis Factoring (PAF) analysis with Promax rotation was conducted to determine the dimensionality of the scale. The result showed that threefactor solutions (eigenvalues greater than 1) with explained variables of 
$65.239 \%$ provided the optimal factor structure. Accordingly, Factor 1 was labelled scanning and searching (Cronbach's $\alpha=.8486$ ); Factor 2 was labelled association and connection (Cronbach's $\alpha=.9128$ ); and Factor 3 was labelled evaluation and judgment (Cronbach's $\alpha=.9517)$. The M, SD, and PAF results are listed in Table 1 . The correlation coefficients between the three different factors ranged from 0.539 to 0.773 .

Table 1. The M, SD, and PAF of the EA scale $(n=341)$

\begin{tabular}{|c|c|c|c|}
\hline Factor/item & M & SD & PAF \\
\hline Scanning and searching & 4.87 & & \\
\hline $\begin{array}{l}\text { I have frequent interactions with others to acquire new } \\
\text { information. }\end{array}$ & 5.06 & .770 & .502 \\
\hline $\begin{array}{l}\text { I always keep an eye out for new business ideas when looking for } \\
\text { information. }\end{array}$ & 5.12 & .798 & .506 \\
\hline $\begin{array}{l}\text { I read newspapers, magazines, or trade publications regularly to } \\
\text { acquire new information. }\end{array}$ & 4.78 & .997 & .520 \\
\hline I browse the Internet every day. & 4.96 & .948 & .799 \\
\hline I am an avid information seeker. & 4.59 & 1.082 & .836 \\
\hline I am always actively looking for new information. & 4.71 & .935 & .795 \\
\hline Association and connection & 4.31 & & \\
\hline $\begin{array}{l}\text { I often make trips to government agencies to inquire about new } \\
\text { business opportunities. }\end{array}$ & 3.66 & 1.191 & .751 \\
\hline $\begin{array}{l}\text { I often make novel connections and perceive new or emergent } \\
\text { relationships between various pieces of information. }\end{array}$ & 4.38 & .953 & .614 \\
\hline I am more skilled than others at predicting how things will unfold. & 4.46 & .902 & .500 \\
\hline $\begin{array}{l}\text { I often think of new solutions after observing the problems of } \\
\text { clients. }\end{array}$ & 4.35 & .929 & .504 \\
\hline I always think outside the box. & 4.67 & .858 & .716 \\
\hline I see links between seemingly unrelated pieces of information. & 4.30 & .970 & .887 \\
\hline I am good at 'connecting dots'. & 4.38 & .930 & .885 \\
\hline $\begin{array}{l}\text { I often see connections between previously unconnected } \\
\text { domains of information. }\end{array}$ & 4.32 & .970 & .731 \\
\hline Evaluation and judgment & 4.18 & & \\
\hline Uncovering potential opportunities comes naturally to me. & 4.37 & .935 & .637 \\
\hline I am particularly attentive to profitable opportunities. & 4.29 & 1.114 & .726 \\
\hline I experience a 'gut feeling' regarding potential opportunities. & 4.27 & 1.091 & .706 \\
\hline $\begin{array}{l}\text { I can distinguish between profitable opportunities and not-so- } \\
\text { profitable opportunities. }\end{array}$ & 4.20 & 1.060 & .965 \\
\hline I have an extraordinary ability to 'smell' profitable opportunities. & 4.27 & .999 & .946 \\
\hline $\begin{array}{l}\text { I have a knack for discerning high-value opportunities from low- } \\
\text { value opportunities. }\end{array}$ & 3.95 & 1.069 & .793 \\
\hline $\begin{array}{l}\text { When facing multiple opportunities, I am able to select the good } \\
\text { ones. }\end{array}$ & 3.90 & 1.075 & .869 \\
\hline
\end{tabular}




\section{Discussion}

Accordingly, the scale developed in the present study can be used for assessing the EA of agrirural entrepreneurs in Taiwan, based on three dimensions: 'scanning and searching,' 'association and connection,' and 'evaluation and judgment.' 'Scanning and searching' refers to the ability of scanning the environment and searching for new information overlooked by others. 'Association and connection' refers to the ability of pulling together disparate information for building coherent alternatives. Finally, 'evaluation and judgment' refers to the ability of making evaluations and judgments regarding the existence of profitable business opportunities.

\section{Study 2: Confirmatory factor analysis and measurement invariance}

\section{Method}

The same EA scale was administered in Study 2 during three conferences on agrirural entrepreneurship held in Taiwan in March 2015. Identical procedures were followed as Study 1. In Study 2, the participants were also agrirural entrepreneurs in Taiwan, serving as the validation sample for verifying the established structure of the EA scale, using a confirmatory factor analysis (CFA). Of the 411 participants, the majority (53.29\%) was male; $23.84 \%$ did not have bachelor's degrees, $34.79 \%$ had bachelor's degrees, and $41.37 \%$ had master's (and above) degrees; $14.84 \%$ ranged in age from 20 to 30 years, $27.01 \%$ ranged from 31 to 40 years, 33.33\% ranged from 41 to 50 years, and $24.82 \%$ ranged from 51 and above. Participation was also voluntary, confidential, and anonymous.

\section{Results}

Confirmatory factor analysis (CFA) with a maximum likelihood estimator was performed using LISREL 8.80 to test the factorial validity of the EA scale. The three-factor solution yielded an acceptable fit $\left(\chi^{2}=927.34, d f=186, p<.005\right.$, RMSEA $=.085, \mathrm{SRMR}=.060, \mathrm{CFI}=.98, \mathrm{NFI}=.97, \mathrm{TLI}=.97)$. The results of the CFA are illustrated in Table 2 . The tests of reliability and validity are reported in Table 3. 
Table 2. The confirmatory factor analysis of the EA scale $(n=411)$

\begin{tabular}{llll}
\hline Item/Factor & $\begin{array}{l}\text { Scanning and } \\
\text { searching }\end{array}$ & $\begin{array}{l}\text { Association and } \\
\text { Connection }\end{array}$ & $\begin{array}{l}\text { Evaluation and } \\
\text { Judgment }\end{array}$ \\
\hline 1 & 0.53 & 0.50 & 0.81 \\
2 & 0.61 & 0.75 & 0.85 \\
3 & 0.64 & 0.79 & 0.90 \\
4 & 0.65 & 0.76 & 0.85 \\
5 & 0.76 & 0.84 & 0.88 \\
6 & 0.85 & 0.88 & 0.86 \\
7 & & 0.89 & 0.82 \\
8 & & 0.86 & \\
\hline
\end{tabular}

Table 3. The reliability and validity of the EA scale $(n=411)$

\begin{tabular}{lllll}
\hline Factors & $\begin{array}{l}\text { Composite } \\
\text { reliability }\end{array}$ & $\begin{array}{l}\text { Measurement } \\
\text { errors }\end{array}$ & $\begin{array}{l}\text { Convergent } \\
\text { validity } \\
\text { (factor loadings) }\end{array}$ & $\begin{array}{l}\text { Discriminant validity } \\
\text { (confidence intervals) }\end{array}$ \\
\hline 1. Scanning and searching & .8449 & $.33 \sim .69$ & $.56 \sim 82$ & $\phi_{1,2: .6016 \sim .7584 ;}$ \\
2. Association and Connection & .9265 & $.18 \sim .87$ & $.50 \sim .90$ & $\phi_{1,3: .4520 \sim .6480 ;}$ \\
3. Evaluation and Judgment & .9496 & $.20 \sim .35$ & $.80 \sim .89$ & $\phi_{2,3: .8008 \sim .8792}$ \\
\hline
\end{tabular}

The analysis of the composite reliability estimates demonstrated that the EA scale had a strong internal consistency. In Study 2, the construct validity was examined in terms of convergent validity and discriminant validity. The convergent validity of each factor was tested by examining the standardized factor loadings. Factor loadings should be .50 or higher for the convergent validity to be achieved. The discriminant validity in this study was tested using confidence interval tests. If the confidence intervals did not include a value of one, discriminant validity was demonstrated. The results reported in Table 3 suggested that convergent validity and discriminant validity were assured.

The degree of measurement invariance of the EA scale across genders was further tested by the researchers. As shown in Table 4, configural invariance was supported. Whether different degrees of measurement were invariant across genders was then examined by the researchers, including factor loadings (metric invariance), response tendency (scalar invariance), factor covariance, factor variance, and error variance. Except for $\chi^{2}$ and $\Delta \chi^{2}$, which are sensitive to large samples, other goodness-of-fit indices, including $\triangle \mathrm{CFI}$, which was proposed to test the measurement invariance, indicated that all models assuming different degrees of invariance were acceptable. The EA scale attained a high degree of measurement invariance across genders. The relationships of covariates with the three EA factors were also found to be invariant (structural invariance). 
Table 4. The measurement invariance tests of the EA scale $(n=411)$

\begin{tabular}{llllllll}
\hline Problem & $\chi^{2}$ & $\Delta \chi^{2}$ & $d f$ & $R M S E A$ & $T L I$ & CFI & $\Delta C F I$ \\
\hline Configural Invariance & 1307.5072 & & 372 & 0.1194 & 0.9479 & 0.9539 & \\
Metric Invariance & 1337.4434 & 29.9362 & 390 & 0.1178 & 0.9497 & 0.9533 & -0.0006 \\
Scalar Invariance & 1370.0177 & 32.5743 & 408 & 0.1162 & 0.9512 & 0.9526 & -0.0009 \\
Factor Covariance Invariance & 1384.5744 & 14.5567 & 411 & 0.1158 & 0.9509 & 0.9520 & -0.0006 \\
Factor Variance Invariance & 1391.3298 & 6.7554 & 414 & 0.1156 & 0.9511 & 0.9518 & -0.0002 \\
Error Variance Invariance & 1433.5986 & 42.2688 & 435 & 0.1142 & 0.9525 & 0.9508 & -0.0010 \\
Structural Invariance & 1455.3056 & 21.707 & 438 & 0.1151 & 0.9519 & 0.9498 & -0.0010 \\
\hline
\end{tabular}

\section{Discussion}

In Study 2, a confirmatory factor analysis was conducted to verify the established factor structure of the previous study. The CFA results confirmed the three-factor solution of the EA scale across genders in Taiwanese agrirural entrepreneurs to ensure the quality of the assessment. A comparison of the scale used in Study 1 and Study 2 with that in Tang et al. (2012) indicates that four additional items were added to 'association and connection,' such as consulting with government sectors, predicting happenings, and observing client problems, indicating specific characteristics of agrirural work. Two additional items were added to 'evaluation and judgment' (natural born ability and attention to profits), also showing specific intrinsic and extrinsic attributes of entrepreneurship.

\section{Study 3: Hypothesis testing and model building}

\section{Method}

In Study 3, a web-based EA scale was developed and administered by the researchers during March 2015. The Survey Monkey tool was chosen to host this study because the program was easy to use and economical. The survey web address was sent by email which provided a convenient and immediate means of response for the participants. A list of 715 agrirural entrepreneurs was obtained from the Ministry of Agriculture in Taiwan. Phone numbers and email addresses of the researchers were provided on the scale. Therefore, problems encountered by participants when answering the scale could be resolved directly. The participants were asked to express their agreement levels regarding their EA. The results were delivered in aggregate and 
anonymous form and the data remained private but could be shared with others if the researchers consented.

No particular incentives were offered for participation, accounting for the low participation rate $(336 / 715=46.99 \%)$. Of the returned emails, 331 were valid. The majority (54.68\%) was male; $23.26 \%$ did not have bachelor's degrees, 33.54\% had bachelor's degrees, and $43.20 \%$ had master's (and above) degrees; $13.90 \%$ ranged in age from 20 to 30 years, $28.40 \%$ ranged from 31 to 40 years, $33.23 \%$ ranged from 41 to 50 years, and $24.47 \%$ ranged from 51 and above.

Study 3 adopted the 40-item IEBFMM (Thompson, 2008), which were measured using a 6-point Likert-type scale ranging from 1 (strongly disagree) to 6 (strongly agree). The IEBFMM items consisted of short phrases that were used to assess the traits associated with each of the FFM dimensions: extroversion (e.g., talkative, energetic, outgoing), openness (e.g., creative, intellectual, artistic), neuroticism (e.g., envious, anxious, jealous), conscientiousness (e.g., efficient, systematic, organized), and agreeableness (e.g., kind, cooperative, warm).

\section{Results}

Prior research has shown the five traits of FFM would interact with each other to affect perceived ability or behavior. Therefore, Hypothesis 3 was tested using LISREL 8.80. Simple slopes and regression lines for each level of the moderator were calculated to examine further the form of interaction for interpreting the interactive effects (Hayes \& Matthes, 2009). The results revealed that only extroversion and openness interacted with each other to affect EA; hence, Hypothesis 3 was partially supported.

Accordingly, high levels of extroversion (high-EX) entrepreneurs perceived their EA in scanning and searching higher than low levels of extroversion (low-EX) entrepreneurs did, no matter under the conditions of high or low levels of openness. The low-EX slope was much steeper than the high-EX slope; showing that the difference between the effects of high-EX and low-EX on the scanning and searching decreased in response to increased levels of openness. When the level of openness was high, the interactive effect of the three levels of EX that influenced EA in scanning and searching approximated each other (Figure 1). The numbers on the axes of Figures 1-3 correspond to points on the Likert-type scales used in the current study. This means that the interactive effect of openness by extroversion for low-EX entrepreneurs was stronger than for high-EX entrepreneurs.

Regarding the interactive effect on association and connection, a similar pattern to that on scanning and searching was shown (Figure 2). Furthermore, 
the interactive effect on evaluation and judgment also had a similar pattern except for the effect under high levels of openness. The data indicated that high-EX entrepreneurs perceived their EA in evaluation and judgment higher than low-EX entrepreneurs did at low levels of openness. However, at high levels of openness, the high-EX entrepreneurs perceived their EA in evaluation and judgment lower than low-EX entrepreneurs did (Figure 3). This indicates that the EA in evaluation and judgment of introverted entrepreneurs increases more quickly in response to their openness than that of extroverted entrepreneurs.

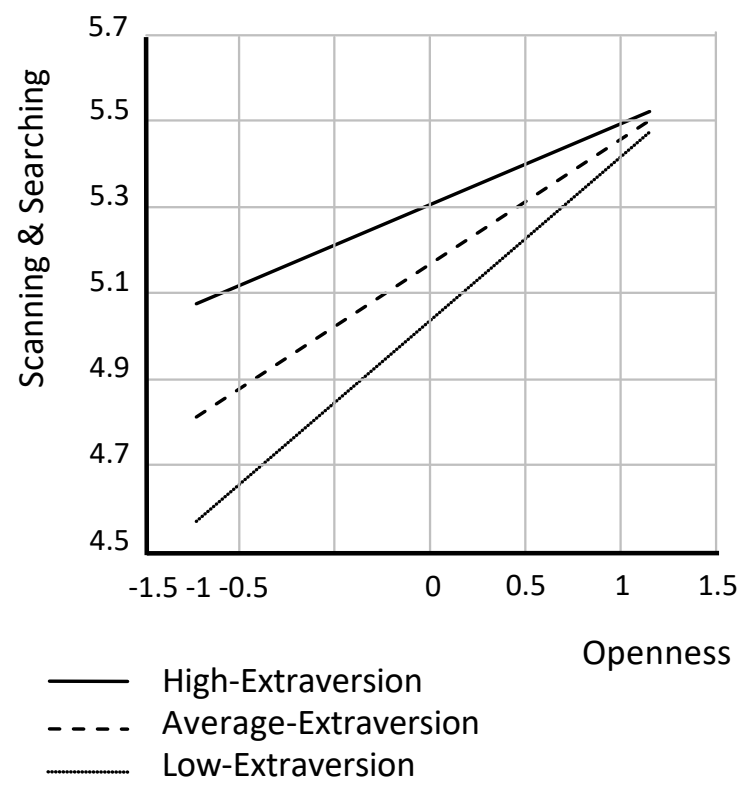

Figure 1. Plots of the interactive effects of openness and extroversion on EA in scanning and searching $(n=331)$ 


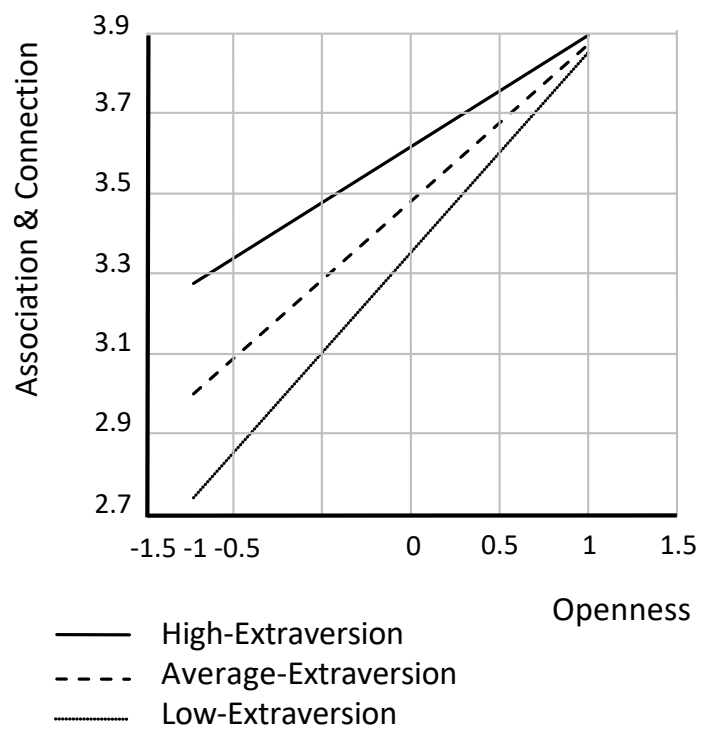

Figure 2. Plots of the interactive effects of openness and extroversion on EA in association and connection $(n=331)$

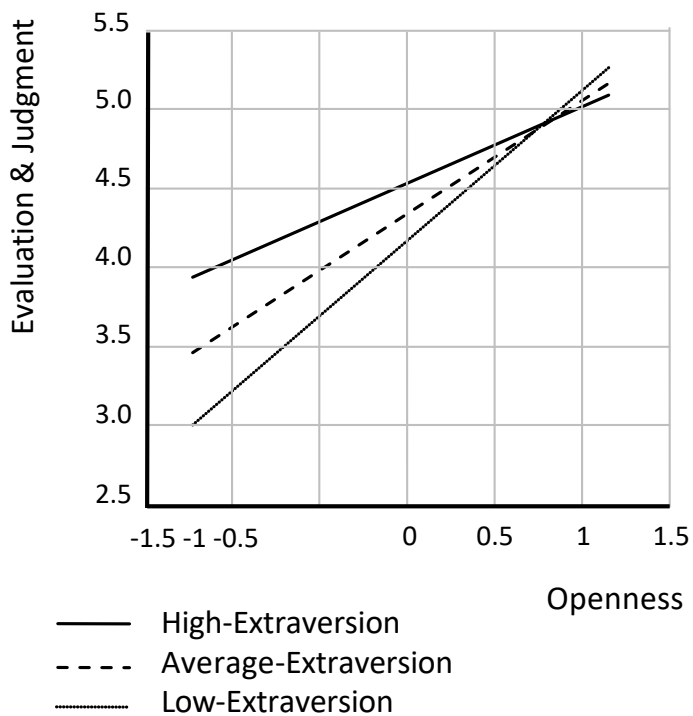

Figure 3. Plots of the interactive effects of openness and extroversion on EA in evaluation and judgment $(n=331)$ 
Structural equation modeling (SEM) combined with maximum likelihood estimation was performed using LISREL 8.80 to test the hypotheses and build the structural model. The structural models were initially supported, but not all the variables were significantly associated with the three dimensions of EA. The researchers removed paths that were nonsignificant and subsequently revised the structural model (Figure 4). The revised model produced a model fit comparable to that of the initial model $\left(\chi^{2}=2121.14, d f=798, p<.005\right.$, RMSEA $=.078, \mathrm{SRMR}=.071, \mathrm{CFI}=.95, \mathrm{NFI}=.92, \mathrm{TLI}=.94)$.

The negative coefficients of 'Openness X Extroversion' mean that the effects of extroversion on the three dependent variables decreased in response to an increase of openness. In addition, the statistics suggested that extroversion and openness affected all the three dimensions of EA, whereas conscientiousness only affected the dimension of scanning and searching; thus, Hypothesis 1 was partially supported. Neuroticism did not have significant effects on any dimension of EA, whereas agreeableness only had a minor positive effect on the dimension of evaluation and judgment, indicating that Hypothesis 2 was not supported. The results of SEM explained a substantial level of variance for the dimensions of scanning and searching $\left(R^{2}=.22\right)$, association and connection $\left(R^{2}=.30\right)$, and evaluation and judgment $\left(R^{2}=.35\right)$.

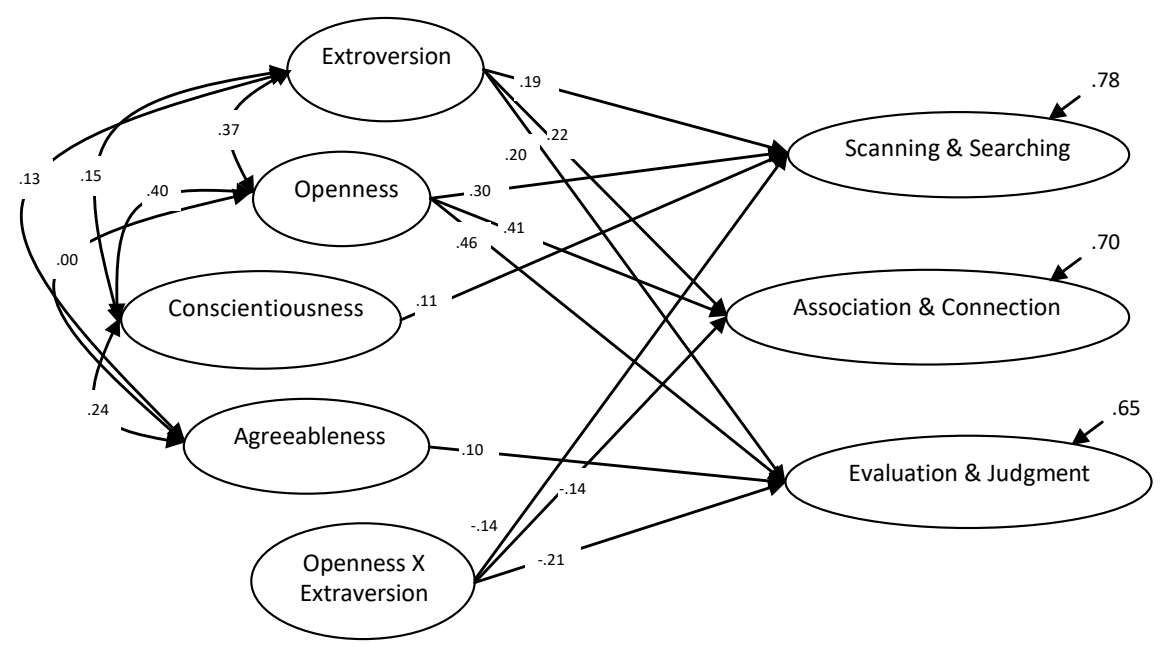

Figure 4. The structural model of personality traits on the EA of agrirural entrepreneurs $(n=331)$ 


\section{Discussion}

People possessing openness are generally described as intellectually curious, broad-minded, and reflective, in addition to having active imaginations, a preference for variety, and an enhanced ability to absorb and combine new information. Their seeking of experiences and cognitive exploration explain why this trait strongly influences all of the EA dimensions. Extrovert people typically enjoy sharing their ideas with others, thereby enabling the cross-fertilization of ideas. They are competent in developing networks and seeking stimulation, explaining why this trait can also reliably predict all of the EA dimensions. Conscientious people tend to be responsible, purposeful, persistent, and achievement-oriented, which explains why conscientiousness positively influences the dimension of scanning and searching instead of the other two. The results lend additional support to the literature on entrepreneurship.

Agreeable people are described as being considerate, caring, and willing to cooperate in conflict situations, thus exhibiting a strong influence on the dimension of evaluation and judgment in the current study. Although this result somewhat contradicts prior research (being a robust predictor of teambased performance), this trait may serve as a facilitator for decision making in evaluation and judgment. In addition, although previous studies have concluded that this trait is unbeneficial to entrepreneurship, it was found to show a nonsignificant effect on every EA dimension, which may result from the factors affecting alertness differing from entrepreneurship or from measurement errors in the current study. Neurotic people tend to provide others with candid feedback regarding their actions. By logical inference, this trait can result in a positive impact on evaluation and judgment. The lack of significant associations in this study warrants further investigation.

Regarding interactive effects, the statistics revealed that extroversion and openness interacted to affect all of the EA dimensions. The data also indicated that lower levels of 'evaluation and judgment' were perceived in entrepreneurs with high EX and high openness than in entrepreneurs with low EX and high openness. The trait of openness has been a strong predictor of human creativity, which may lead to illegal or immoral decisions that harm entrepreneurial innovation and firm performance (Cropley, 2010; Del-CorteLora, Vallet-Bellmunt, \& Molina-Morales, 2015). Extroverted people enjoy interacting with people and may compromise their judgment when excessive openness to others is involved. 


\section{GENERAL DISCUSSION}

As discussed, improving agrirural entrepreneurship has currently become a worldwide agenda. Accurately recognizing and selecting market opportunities are considered critical abilities in an effective entrepreneur. However, EA is not a quality that agrirural workers widely possess. Because of this research gap, this paper presents a series of three studies that developed and validated an agrirural EA scale, in addition to testing the effects of entrepreneur personality on their EA levels. According to the results, EA can be assessed using three dimensions: 'scanning and searching,' 'association and connection,' and 'evaluation and judgment.'

'Scanning and searching'refer to the ability of constantly scanning the environment and deliberately searching for new information, changes, and shifts overlooked by others. 'Association and connection' refers to the ability of pulling together previously disparate information and building them into coherent alternatives, denoting how entrepreneurs respond cognitively to and process new information clues. Finally, 'evaluation and judgment' refers to the ability of making evaluations and judgments about the new changes, shifts, or information and deciding whether they reflect a business opportunity with profit potential.

The extent to which each dimension may be applied warrants further investigation. For example, because of its definition, EA has been treated as an entrepreneurial ability; however, does perceiving it as an entrepreneurial behavior change the investigation? By using measures of behavior observation or an action test, research may provide deeper insights into entrepreneurial performance than the current study did. Additional explorations may include an analysis of EA differences and dimensions in various domains (e.g., high technology, social welfare, health care, finance and banking), the practical implications of these differentiations, the factors influencing them, and how these factors may function differently at individual, team, organizational, societal, and global levels. Answering these questions may yield valuable insights for developing and operating agrirural enterprises.

Regarding traits that directly affected scanning and searching, openness was found to be the most influential trait, followed by extroversion and conscientiousness. In addition, openness and extroversion were identified to be traits that affected association and connection. Regarding evaluation and judgment, the traits of openness and extroversion remained dominant influences, followed by agreeableness. Although possible explanations and inferences were discussed, several uncertainties (e.g., neuroticism's lack of influence on agrirural EA, the positive effect of agreeableness on agrirural EA, 
and the minor impact of conscientiousness and agreeableness on agrirural EA) warrant further investigation.

In addition, the results demonstrated interactive relationships between extroversion and openness on all of the EA dimensions. Information and evidence regarding the traits and their interactions can determine the EA dimensions that are crucial for the optimal deployment of human resources within an agrirural enterprise, which could maximize the contributions of the enterprise. In addition, many open questions require clarification, particularly regarding the contribution of intrinsic characteristics and contextual variables to the shaping of EA. For example, how do intrinsic characteristics, such as motivation, emotions, or self-efficacy, influence agrirural EA? How can these characteristics enhance entrepreneurial performance? What are the contextual variables, such as leadership, incentive system, team climate, and organizational culture, that affect agrirural EA? How do these intrinsic characteristics and contextual variables interact to influence agrirural EA? The answers to these questions can provide insights into employee recruitment, development strategies, and retention policies, in addition to elucidating organizational design, development, and management in agrirural enterprises.

This study contributes to entrepreneurship literature by theorizing and testing how the interaction of personality traits can benefit the EA of agrirural entrepreneurs. Although this study elucidates topics pertaining to entrepreneurial research, several study limitations should be mentioned. First, the self-reported scale, which was used to ensure the empirical validity and to simplify the survey administration process, may have caused common method bias. However, the study questionnaire contained no sensitive questions, and its consistency with previous studies supports the measures. This study adopted simple measures, selected the instruments carefully, and offered necessary feedback after the survey to reduce such bias and minimize this limitation. Second, only agrirural entrepreneurs who attended the conferences in Taiwan from December 2014 to March 2015 were included. The limited subject scope and investigation period may cause inevitable bias. Additional subjects and an extended survey period should be considered in future studies to expand the generalisability of the findings. Third, the perspectives of external organizations, such as farmers' associations and cross-industrial coordination companies, were not investigated in this study. Future studies should consider the different effects of internal and external perceptions regarding agrirural EA. 


\section{CLOSING REMARKS}

Despite the global economic recession, agriculture remains the basis of socioeconomic development. Governments worldwide are actively formulating relevant policies to aid in the restructuring and upscaling of their agricultural industries. Providing essential guidance in agricultural entrepreneurship for diversifying rural regions should be the central concern. Recognizing and interpreting opportunities are the most crucial abilities that should be fostered and empowered in developing agrirural entrepreneurship, with the needs of related research being supported. Therefore, despite the aforementioned limitations, the results of the current study provide a new understanding of how agrirural EA can be assessed more practically and how the personality traits of entrepreneurs can predict various dimensions of agrirural EA.

During the research process of this series of studies, the researchers noted that an increasing number of younger people had devoted themselves to agrirural entrepreneurship in Taiwan. The younger agrirural entrepreneurs have exhibited increased EA, highlighting their entrepreneurial potential. Although developing agrirural enterprises in Taiwan remains at an early stage, people who have been working in this field can initiate a larger movement, thereby educating and inspiring Taiwanese society. The researchers believe that Taiwan will follow in the footsteps of successful agrirural enterprises in the West and enable innovators to have a socioenvironmental impact across Asia, contributing as a whole to a globally sustainable society.

\section{References}

Ariani, D.W. (2013). Personality and learning motivation. European Journal of Business and Management, 5(10), 26-38.

Bachnik, K., \& Szumniak-Samolej, J. (2018). Social initiatives in food consumption and distribution as part of sustainable consumption and sharing economy. Journal of Entrepreneurship, Management and Innovation, 14(2), 101-122.

Baer, M., Oldham, G., Jacobsohn, G.C., \& Hollingshad, A.B. (2008). The personality composition of teams and creativity: The moderating role of team creative confidence. Journal of Creative Behavior, 42(4), 255-282.

Baron, R.A. (2006). Opportunity recognition as pattern recognition: How entrepreneurs "connect the dots to identify new business opportunities." Academy of Management Journal, 20(1), 104-119.

Barrick, M.R., Mount, M.K., \& Judge, T.A. (2001). Personality and performance at the beginning of the new millennium: What do we know and where do we go next? International Journal of Selection and Assessment, 9(1/2), 9-30. 
Bernardin, H.J., Cooke, D.K., \& Villanova, P. (2000). Conscientiousness and agreeableness as predictors of rating leniency. Journal of Applied Psychology, 85(2), 232-236.

Brandstätter, H. (2011). Personality aspects of entrepreneurship: A look at five meta-analyses. Personality and Individual Differences, 51(3), 222-230.

Chen, C.-C., Yueh, H.-P., \& Liang, C. (2016). Strategic management of agribusiness: Determinants and trends. Journal of Entrepreneurship, Management and Innovation, 12(4), 69-97.

Chia, C.-C. \& Liang, C. (2016). Influence of creativity and social capital on the entrepreneurial intention of tourism students. Journal of Entrepreneurship, Management and Innovation, 12(2), 151-168.

Cropley, D.H. (2010). The dark side of creativity: A differentiated model. In D.H. Cropley, J. Kaufman, A.J. Cropley, \& M.A. Runco (Eds.), The Dark Side of Creativity (pp. 360-373). Cambridge, UK: Cambridge University Press.

Del-Corte-Lora, V., Vallet-Bellmunt, T., \& Molina-Morales, F.X. (2015). Be creative but not so much. Decreasing benefits of creativity in clustered firms. Entrepreneurship \& Regional Development, 27(1-2), 1-27.

Dutta, D.K., \& Crossan, M.M. (2005). The nature of entrepreneurial opportunities: Understanding the process using the $4 \mathrm{l}$ organizational learning framework. Entrepreneurship Theory and Practice, 29(4), 425-449.

Estahbanaty, S.S.M. (2013). How to increase agricultural entrepreneurial skills. European Online Journal of Natural and Social Sciences, 2(3), 1244-1251.

Flora, C.B., \& Flora, J.L. (1990). Developing entrepreneurial rural communities. Sociological Practice, 8(1), 197-207.

Gaglio, C.M., \& Katz, J.A., (2001). The psychological basis of opportunity identification: Entrepreneurial alertness. Small Business Economics, 16(2), 95-111.

Goldberg, L.R. (1992). The development of makers for the Big-Five factor structure. Psychological Assessment, 4, 26-42.

Hayes, A.F., \& Matthes, J. (2009). Computational procedures for probing interactions in OLS and logistic regression: SPSS and SAS implementations. Behavior Research Methods, 41(3), 924-936.

Ilies, R., Johnson, M.D., Judge, T.A., \& Keeney, J. (2011). A within-individual study of interpersonal conflict as a work stressor: Dispositional and situational moderators. Journal of Organizational Behavior, 32(1), 44-64.

Janowski, A. (2018). Personality traits and sales effectiveness: The life insurance market in Poland. Journal of Entrepreneurship, Management and Innovation, 9(2), 5-28.

Khan, M.T., Khan, N.A., Ahmed, S., \& Ali, M. (2012). Entrepreneurship development: One of the ways of rural development through rural human resource development (a review). International Journal of Business and Behavioral Sciences, 2(8), 14-23.

Kirzner, I.M. (1997). Entrepreneurial discovery and the competitive market process: An Austrian approach. Journal of Economic Literature, 35(1), 60-85. 
LePine, J.A. (2003). Team adaptation and postchange performance: Effects of team composition in terms of members' cognitive ability and personality. Journal of Applied Psychology, 88(1), 27-39.

Liang, C.-T., Peng, L.-P., Yao, S.-N., \& Liang, C. (2015). Developing the social enterprise performance scale and examining the effects of entrepreneurs' personality traits. Journal of Entrepreneurship, Management and Innovation, 11(3), 89-116.

Lim, W.L., Lee, Y. L.-E., Ramasamy, R. (2015). Personality, prior knowledge, social capital and entrepreneurial intentions: Entrepreneurial alertness as mediator. Global Journal of Business and Social Science Review, 1(2), 538-548.

Liu, H.-C., Ip, C. Y., \& Liang, C. (2018). A new runway for journalists: On the intentions of journalists to start social enterprises. Journal of Entrepreneurship, Management and Innovation, 14(2), 83-100.

Lumpkin, G.T., \& Lichtenstein, B.B. (2005). The role of organizational learning in the opportunity-recognition process. Entrepreneurship Theory and Practice, 29(4), 451-472.

Luna-Reyes, L. F., Durán-Encalada, J. A., \& Bandala, E. R. (2013). Exploring alternatives for sustainable development in the Tamiahua wetlands. Journal of Entrepreneurship, Management and Innovation, 9(2), 5-28.

McCrae, R.R., \& Costa, P.T., Jr. (1991). The NEO personality inventory: Using the five-factor model in counseling. Journal of Counseling and Development, 69(4), 367-372.

McMullen, J.S., \& Shepherd, D.A. (2006). Entrepreneurial action and the role of uncertainty in the theory of the entrepreneur. Academy of Management Review, 31(1), 132-152.

Niemelä, T. (2015). Farm entrepreneurs' intentions to develop pluriactive business activities in Finland. Journal of Entrepreneurship, Management and Innovation, 11(3), 117-141.

Omri, A., \& Boujelbene, Y. (2015). Entrepreneurial team: How human and social capital influence entrepreneurial opportunity identification and mobilization of external resources. Journal of Entrepreneurship, Management and Innovation, 11(3), 25-42.

Pease, C. R., \& Lewis, G. J. (2010). Personality links to anger: Evidence for trait interaction and differentiation across expression style. Personality and Individual Differences, 74, 159-164.

Heidari-Sareban, V. (2012). Factors affecting farmers boost entrepreneurship in rural areas: A case in Meshginshahr, Geography, 35, 263-278.

Saxena, S. (2012). Problems faced by rural entrepreneurs and remedies to solve it. IOSR Journal of Business and Management, 3(1), 23-39.

Shane, S. (2000). Prior knowledge and the discovery of entrepreneurship opportunities. Organization Science, 11(4), 448-469.

Shane, S., Nicolaou, N., Cherkas, L., \& Spector, T.D. (2010). Do openness to experience and recognizing opportunities have the same genetic source? Human Resource Management, 49(2), 291-303. 
Shepherd, D.A., \& DeTienne, D.R. (2005). Prior knowledge, potential financial reward, and opportunity identification. Entrepreneurship Theory and Practice, 29(1), 91-112.

Swickert, R.J., Hittner, J.B., \& Foster, A. (2010). Big Five traits interact to predict perceived social support. Personality and Individual Differences, 48, 736-741.

Tang, J., Kacmar, K.M., \& Busenitz, L. (2012). Entrepreneurial alertness in the pursuit of new opportunities. Journal of Business Venturing, 27(1), 77-94.

Thompson, E.R. (2008). Development and validation of an International English Big-Five Mini-Markers. Personality and Individual Differences, 45(6), 542-548.

Van Der Molen, H.T., Schmidt, H.G., \& Kruisman, G. (2007). Personality characteristics of engineers. European Journal of Engineering Education, 32(2), 495-501.

Wilson, K., \& Morren Jr., G. E.B. (1990). Systems Approaches for Improvement in Agriculture and Resource Management. New York: Macmillan.

Wolff, H.-G., \& Kim, S. (2012). The relationship between networking behaviors and the big five personality dimensions. Career Development International, 17(1), 43-66.

Zhao, H., \& Seibert, S. E. (2006). The Big Five personality dimensions and entrepreneurial status: A meta-analytical review. Journal of Applied Psychology, 91(2), 259-271.

\begin{abstract}
Abstrakt
Badania akademickie w zakresie przedsiębiorczości agrarnej i rozpoznawania szans sq niewielkie. Z powodu tej luki badawczej przeprowadzono serię trzech badań, aby rozwinqć miarę czujności przedsiębiorczej (EA) w środowiskach agroturystycznych, która jest empirycznie ważna i łatwa w administrowaniu oraz analizuje, w jaki sposób cechy osobowości przedsiębiorców rolnych wpływajq na ich EA. Wyniki pokazały, że zarówno ekstrawersja, jak i otwartość wpłynęły na wszystkie wymiary EA, podczas gdy sumienność wpłynęła tylko na skanowanie i wyszukiwanie, a ugodowość wpłynęła tylko na ocenę i osq̨d. Wyniki pokazały również interaktywne zależności między ekstrawersja a otwartościq dla wszystkich wymiarów EA. Nasze wyniki zapewniaja nowe zrozumienie, w jaki sposób EA można ocenić bardziej praktycznie i jak cechy osobowości moga przewidywać różne wymiary EA agriruralnego.
\end{abstract}

Słowa kluczowe: przedsiębiorcy agriruralni, czujność przedsiębiorcza, cechy osobowości, rozwój skali. 


\section{Biographical note}

Chaoyun Liang is a Professor in the Department of Bio-Industry Communication and Development, National Taiwan University, Taipei, Taiwan. He gained his Ph.D. degree in the Instructional Systems Technology program at Indiana University, USA. His research interests focus on: imagination \& creativity, entrepreneurship \& social enterprise, and agrirural communication \& marketing. Professor Liang can be reached via cliang@ntu.edu.tw. 
